
\title{
R Research Soure \\ Influence of Access To Finance On The Competitive Growth of SMEs in Lesotho.
}

Donald Edes Osakpamwan Amadasun ( $\square$ edesamas@yahoo.com )

University of South Africa College of Economic and Management Sciences https://orcid.org/00000002-1611-5983

\section{Ashley T. Mutezo}

University of South Africa - Muckleneuk Campus: University of South Africa

\section{Research}

Keywords: financial information access, bank and business support services, the structure of the bank, collateral requirement, competitive growth, small and medium enterprises

Posted Date: November 15th, 2021

DOI: https://doi.org/10.21203/rs.3.rs-1027267/v1

License: (1) This work is licensed under a Creative Commons Attribution 4.0 International License. Read Full License 


\title{
Influence of Access to Finance on the Competitive Growth of SMEs in Lesotho
}

Author: Donald O. E. Amadasun ${ }^{1 *}$ Limkokwing University of Creative Technology, Maseru, Lesotho.

Co-author: Ashley T. Mutezo ${ }^{2 *}$ University of South Africa, Pretoria, South Africa.

Corresponding author: Donald O.E. Amadasun (PhD), email: edesamas@yahoo.com.

Co-author: Prof. Ashley. A.T. Mutezo (PhD), muteza@unisa.ac.za.

\begin{abstract}
:
Background: Access to finance is identified as one of the biggest problems faced by Small and Medium-Sized Enterprises (SMEs) in most developing economies. Consequently, access to finance has been identified as a dominant constraint facing the SMEs sector in Lesotho. This paper established the factors of access to finance that influence the competitive growth of the SME sector in Lesotho. The factors addressed include financial information access, bank and business support services, the structure of banks and collateral requirements by the financial sector.

Findings: The results from our analysis indicated that there is a relationship between independent variables of financial information access, Bank and business support service, the structure of banks and the collateral requirement by commercial banks and such influence SMEs capacity to attain competitive growth in Lesotho. In addition, the results indicated that Basotho entrepreneurs and managers see the predictors as critical factors of access to finance that constrained most enterprises access to needed credit from banks and such influence SMEs capacity to attain competitive growth in Lesotho.

Conclusions: The study concludes that access to finance significantly affect the competitive growth of SMEs in Lesotho. Thus, this study suggests that several specific and harmonized financial policy actions are needed in the Lesotho financial market to identify enabling policy that ease enterprises access to adequate funding programs. These funding programs should target improved financial schemes that are coordinated, competitive and directed towards SMEs access to finance; harmonized credit policy which guarantees a win-win for SMEs loan applicants and the financial market operators.
\end{abstract}

Keywords: financial information access, bank and business support services, the structure of the bank, collateral requirement, competitive growth, small and medium enterprises. 


\section{Introduction}

The extant literature on access to finance in entrepreneurship is immense. However, with the current rapid upsurge in many market-driving economies, most small and medium-sized enterprises (SMEs) face inadequate access to finance which constrains their capacity to attain competitive growth. According to the entrepreneurship literature, SMEs foster economic development in developed and developing countries, for example, in driving creativity and innovation with significant contribution to countries' GDPs when they have access to finance (Ghosh, 2016). Unfortunately, most SMEs in developing countries continue to face huge access paucity of credit constraints from banks and as such, constrains their growth.

According to Mazanai and Fatoki (2012), access to finance is one of the biggest problems SMEs face in most developing countries, mainly from banks. Going by the general norm that the availability of finance is a critical source factor to SMEs competitive operation, commercial banks who are the main source of finance tend to be less responsive to them. Singh and Kaur (2014) allude that this is attributive to many commercial banks, in the greed of making profits, consider SMEs most risky and are less interested in programs regarding critical credit schemes that allow them access to loans. In the same context, some studies accentuate that most SMEs suffer from limited access to financial resources, and such constrain their capacity to grow, respond to competitors in the market and diversify their business operations (Subairu, 2016; Quan, Ghosh, 2016).

In the context of Lesotho, SMEs are those enterprises that employ between 6 to 50 employees (GoL, 2016:5). In Lesotho, a study conducted by the EU (2012:4) confirms that access to finance is highly problematic for locally-owned private SMEs. Similarly, a survey carried out by the EU (GoL, 2012) for the Ministry of Trade in Lesotho revealed that most SMEs owned and operated by Basotho face difficulty accessing bank loans needed for the effective operation of their businesses. According to the study, $71 \%$ of small enterprises and $56 \%$ of medium enterprises indicated constraints in access to bank credit. The factors that constituted high constrain to the SMEs' access to finance were: high-interest rates and lack of appropriate collateral, as indicated by $89 \%$ and $86 \%$ of the respondents, respectively. In addition, the phenomenon of 'discouraged borrowers' is high, as issues attributed to the aforementioned socioeconomic and institutional factors exacerbate many SMEs from qualifying for credit from banks in Lesotho.

In Lesotho, the Government of Lesotho has recognised that many Basotho SMEs face high constrain in accessing needed finance contributing to a high failure rate of such enterprises (GoL, 2016). A literature search indicated that less focus had been paid to the critical factors that constrained most SMEs access to finance, which are seen to influence their capacity to attain competitive growth in Lesotho. Thus, this paper argues that such critical factors are constraints to adequate access to finance, causing most local SMEs (Basotho-owned and operated SMEs) to suffer from severe market ineffectiveness, business ineptness, and various setbacks in the market environment to attain growth. Evidence currently indicates that the number of SMEs in Lesotho has decreased by 39.15\%, from 125000 in 2010 to 76067 in 2016 
(GoL, 2016:10). Of the 39.15\%, Basotho SMEs seem to be most affected. In addition, records show that less than $10 \%$ of Basotho SMEs survive, thrive, and attain substantial growth (EU, 2012; Mokoatleng, 2015), and this may be attributive significantly to SMEs inadequate access to finance from banks.

Despite SMEs' remarkable and indisputable contributions to Lesotho's aggregate economic performance, in terms of employment generation, business creation and development, they are still victims of credit constraint and rationing from banks (Amadasun, 2013; 2020). Thus, this paper opines that access to finance remains a major obstacle and may have worsened the prospects for most SME businesses to attain competitive growth in Lesotho.

According to the entrepreneurship literature, access to finance plays a major role in SMEs' capacity to effectively operate and achieve significant growth. Therefore this paper considers the four core factors namely, financial information access (FIA), bank and business support services (Bbss), the structure of bank (SoB) and collateral requirement (COLLATA) as predictors that constrain SMEs access to finance and such influence their capacity to attain competitive growth in Lesotho. This is because we cannot avoid the fact that the financial access crisis exists and is affecting SMEs effective operations, particularly from the aforementioned independent variables in various economies, in particular in the context of Lesotho.

In Lesotho, current data indicates that the formal SMEs stands at about $18 \%$ of the total number of the micro, small and medium-sized enterprises (MSMEs) sector, while the rest (82\%) operate as informal businesses (GoL, 2016:6). This percentage seems not improving particularly for Basotho SMEs, probably because most of them find it challenging to raise adequate funds from most banks because they are often viewed as relatively risky and lack pragmatic and standardized track records.

Thus, this paper considers the four core constructs, namely, financial information access, bank and business support services, structure of bank and collateral requirement, as factors of access to finance, which influence SMEs' capacity to attain competitive growth in Lesotho. This is because, to the best of the researcher's knowledge, hardly any study has considered the four core constructs as joint factors that constrain SMEs' access to finance in the Lesotho context. Therefore, the four factors mentioned above form the gauge to measure SMEs' access to finance from banks that constrain their competitive growth in Lesotho.

\section{Literature Review}

\section{Theoretical Review}

\section{The credit rationing theory}

Theoretically, finance literature indicates a well-documented explanation in the theory that explains finance issues to the SMEs, and to assess the aforementioned is to review its fits to the enterprise. To the best of the researcher's knowledge, the review of strategic literature indicates that no universally accepted theory in the entrepreneurship literature has been adopted as the sole influence of SMEs access to finance. Hence, it is essential to review an existing strategic theory such as "the credit rationing theory" on enterprise access to finance to guide the current study's analysis. 
According to the strategic literature, the "financing gap analysis" is the credit rationing theory" by Stiglitz and Weiss (1981) and is one of the major theories which argues the agency problems (a conflict of interest between bank (agent) and the owners of the enterprise, and the information asymmetries as significant reasons why SMEs are constrained access to finance. Stiglitz and Weiss (1981:16) argued that the presence of financial constraints on SME businesses is due to informational problems (that is, principal-agent issues) and transactional costs. This informed this paper that due to the lack of collateral/income, most banks classify SMEs as "non-bankable" enterprises and high-risk borrowers and are likely to be less interested in programmes that favour them. In further analysis, rationing arises to discourage most SMEs even in a competitive credit market using interest rates and bank charges as weapons that affect demand and the risk profile of the bank's customers (Kremp and Sevestre, 2013). Despite this, Stiglitz and Weiss' analysis focuses on the "informational problem and transactional cost" paradigms. Both paradigms are skewed to the borrower's capabilities to repay the loan. This suggests that the asymmetries information exists when the credit officers do not have 'perfect' information of the funding proposal base.

Although Stiglitz and Weiss (1981) compelling explanations of why credit rationing behaviour still exists with financial institutions, the theory has not addressed pecuniary issues of access to finance such as bank and business support services, the structure of banks and the collateral requirement that may have caused banks rationing to potential customers even in a competitive credit market. Hence, banks insisting on high interest rates and bank charges may have affected demand and the risk profile of the bank's customers. Subsequently, the fact remains that, in many developing economies like Lesotho, that most banks may not have perfect information about the creditworthiness of prospective borrowers. Thus, the likelihood of the supply of loans to be backward bending at rates above the bank's optimal rate (Mazanai and Fatoki, 2012). This implies that financial exclusion may persist even in market optimum. Whether such an enterprise is excluded based on the price barriers or financial exclusion due to high idiosyncratic risk or poor project quality could be due to market imperfection such as asymmetric information. This paper considers that such are peculiar to the four factors of access to finance: financial information access, bank and business support services, the structure of banks, and collateral requirement as constraining to SMEs access to bank loans.

In Lesotho, access to credit constraints tends to be very visible with SMEs (EU, 2012). Empirical studies such as Makhetha and Sebolelo (2015), Mokoatleng (2015) are some studies on access to finance of SMEs in Lesotho, but their studies omitted constructs such as; financial information access, structure of bank and bank and business support services as critical factors of access to finance that limits bank funding which influences the competitive growth of SMEs.

To bridge the gap of access to finance, this paper suggests that although various studies have considered access to finance a huge challenge to SMEs in most developing economies, there is a gap in entrepreneurship literature that has omitted the four access to finance factors mentioned above of in Lesotho context. Thus, this study aims to determine the constructs (financial information access, bank 
and business support services, structure of bank and collateral requirement) as factors of access to finance influence the competitive growth of SMEs in Lesotho.

\section{Empirical review}

Financial information access

Compared to large enterprises, many SMEs face intense competitive disadvantages in accessing the financial information needed to access adequate credit from banks, typically due to the nature of their businesses. Although, the nature of SMEs and their capacity do influence on the constraints they face regarding access to needed funds, they require adequate information to identify potential suppliers of credit funds (Osano \& Languitone, 2016). According to Aleksandr et al. (2016), SMEs' access to needed credit funds is highly influenced by the degree of access to adequate financial information about potential suppliers and the available credit products of the bank. Many SMEs are denied access to financial credit by banks because they lack the necessary information and awareness related to funding from the financial market. Following the Stiglitz and Weiss (1981) credit rationing theory, from the lender's perspective, banks cannot distinguish among borrowers based on the limited financial information available to them. As a result, it leads to acute information asymmetry between the credit officers and SME applicants.

In addition, due to inadequate information about potential SME applicants, banks are unwilling to take the risk of financing them. In many cases, commercial banks consider most SMEs as high risk, such that they are considered highly indebted with a small capacity to meet prompt debt repayments (Aleksandr et al., 2016). Consequently, most commercial banks are reluctant to provide the necessary information that could encourage demand from SMEs, and it becomes problematic for these enterprises to obtain a commercial loan. Based on fewer options, many SMEs are forced to access bank credit under stringent circumstances that are not favourable to their enterprises' flexible repayment capacity, which, as a result, affects their competitive growth in the market.

However, the following are socio-economic reasons why most banks consider limited financial information as a strategic tool to controlling credit extension to SMEs:

- High administrative costs of lending to small business applicants;

- Information asymmetries in the financial market; and

- The loan officer's perception of the SMEs being highly risky and including bias of business ownership.

Therefore, since many bankers lack perfect knowledge of potential borrowers' solvency, SMEs may continue to face credit exclusion from the financial market.

Hypothesis 1

$H_{0}$ : Financial information access has no statistically significant influence on SMEs competitive growth. $H_{1}$ : Financial information access has statistically significant influence on SMEs competitive growth. 


\section{Bank and business support services}

SMEs' access to financial and business support resources influences the enterprises' quality in the business environment (Fetisovová et al., 2012). According to Zeebaree and Siron (2017), the main reason for government and agency supports for enterprises is to enhance their operational capacity, competitiveness and to attain market growth. While enabling support programs that cover a wide range of services which could start from creating, developing, training, marketing and consultancy services for SMEs, many of these enterprises are worse hit by crucial enabling resources such as the bank loan as a major challenge that hinders their survival and growth (Mazanai and Fatoki, 2012). By extension SMEs are constrained by bank and business support resources that should include granting direct and indirect financial credits, managing and advisory services on different aspects of the enterprises to make them competitive; promote start-up businesses by granting them resources to strengthen their operational bases like subsidies and training programs (Amadasun, 2020). According to Zeebaree and Siron (2017), such enabling resources are management training skills and integrated technology capabilities of SME entrepreneurs or managers that influence the performance of enterprises. Gathii and Ngura (2015) found that few SMEs entrepreneurs had obtained management training skills, and few possess integrated technology capability in their business operations. As a result, it impedes their chances to qualify and obtain bank loans.

Most SMEs are exceptionally susceptible to the whims and dynamics of the business environment with less business support and guarantees from the government and agencies. In this study, the inability of the enterprises to access loans is considered a fundamental institutional weakness of bank and business support services, and as such, constrains most SMEs competitive growth in Lesotho. The lack of bank and business support services further exacerbates SMEs' vulnerability to bank credit, which could be another reason why credit rationing persists in the competitive credit market of Lesotho.

In addition, inadequate support programmes designed for and which strive to make SMEs attractive and competitive seem to constrain their access to finance and competitive growth. A study indicates that bank lenders simply attach high bank charges and high-interest rates to a loan to discourage SMEs entrepreneurs' who lack adequate operational support guarantee schemes (Moro and Fink, 2013). Although banks aim to minimise risky borrowers, it appears that banking schemes and insurance institutions that are supposed to bridge the link of credit to SMEs are inadequate in many smaller and developing economies, and this implies that the lenders' supply of credit funds will indicate a backward curve, even at rates higher than the bank's equilibrium rates.

Hypothesis 2

$H_{0}$ : Bank and business support services have no statistically significant influence on SMEs competitive growth.

$H_{1}$ : Bank and business support services have statistically significant influence on SMEs competitive growth. 


\section{Structure of bank}

Most SMEs' limited access to financial credit is a consequence of the financial structure of banks because competition in the financial market is an antidote for the competitive costs of financial products and services in the banking sector (Amadasun, 2020). As such, this grossly affects the competitive growth of enterprises in many developing economies.

Although many factors can be considered in explaining SMEs' constraints of access to finance, the level of competition in the banking industry, in particular, determines the price of financial services or products offered to loan applicants or customers. For example, Osano and Languitone (2016) suggest that the lack of competition in the financial sector leads to obstacles for SMEs in accessing credit. Low competition in the banking sector may affect the overall stability in the financial market. It may affect the effectiveness of the financial service delivery to applicants (SMEs) who need financial credit the most. Thus, direct competition in the banking sector may positively influence new entry, growth, and the existing banks' effectiveness and affect SME applicants' credit for bank loans.

Low competition in the banking sector is an implication of a high regulatory regime, where the financial market's competitiveness does not rely on the actual market structure but relies on the country's regulatory regime. Although there may not be a clear relationship between the interference of government on the intermediation process of the banking system's effectiveness and the enterprises' access to credit, regulatory restrictions probably affect the overall effectiveness and efficiency in the financial market (Osano and Languitone, 2016). Substantively, El-Said et al. (2015) argued that the low competition in the banking sector implies a high regulatory regime that excludes many SMEs borrowers from access to bank finance. This effectively forces SMEs to utilise micro-credit loans from informal lenders that are barely adequate, assuming that there would be an enabling environment for their enterprises.

Although SMEs are considered important actors in economic growth in Lesotho, the non-standardised designs of its credit guarantee scheme could result from the bank's structure. Lesotho has three major banks (First National Bank, Nedbank and Standard Lesotho Bank), of which the primary ownership is foreign-owned, and as a result, the banks are less likely to pursue more information and better enforcement mechanisms. This probably excludes many Basotho SMEs from the financial mainstream through the enforcement of stringent credit conditions.

Therefore, the bank structure that does not promote direct competition in the financial market may severely impact the banking sector's effective, efficient stability, and as such, place constraints on SMEs' access to finance and affect their competitive growth in Lesotho.

Hypothesis 3

$H_{0}$ : Structure of banks has no statistically significant influence on SMEs competitive growth. $H_{1}$ : Structure of bank has a statistically significant influence on SMEs competitive growth. 


\section{Collateral requirement}

For many SMEs, the situation is exacerbated by the banks' collateral requirement on the loan before any credit is granted (Mazanai \& Fatoki, 2012). A study by Osano and Languitone (2016) in the Maputo CBD in Mozambique found that collateral requirement is one major significant factor that hinders SMEs access to bank credit. Mazanai and Fatoki (2012) confirm that $45 \%$ of SMEs are denied access to finance due to a lack of collateral security; hence, the survival rate of SMEs is less than $20 \%$ in South Africa. Kihimbo et al. (2012) study in the Kakamega Municipality in Kenya indicated that before banks consider SMEs loan requests, they demand equivalent collateral deposits. This implies that banks in Kakamega Municipality require collateral of $100 \%$ or above to consider credit loan proposals, equivalent to the financial credits they intend to grant to borrowers of the loan (Kihimbo et al., 2012). Bhalla and Kaur (2012) findings showed that banks' collateral requirements discourage most SMEs from accessing credit loans, and even more, they are disenfranchised due to banks' perception that they are very risky borrowers with low capacity to repay borrowed loans. A study by Ingabire et al. (2016) in Rwanda also considers lack of collateral to be one of the major challenges SMEs face.

Though it may be justifiable for banks to see this as a strategic approach to avoiding losses in lending to borrowers with less capacity to repay credit loans, SMEs need to access needed credits that is adequate for the enterprises effective and efficient performance to attain competitive growth in the dynamic business environment like in Lesotho.

\section{Hypothesis 4}

$H_{0}$ : Collateral requirement has no statistically significant influence on SMEs competitive growth.

$H_{1}$ : Collateral requirement has a statistically significant influence on SMEs competitive growth.

\section{Competitive Growth of SMEs}

According to Matharu, Changle and Chowdhury (2016), competitive growth is a fundamental criteria measure that include; autonomy, independence, and effectively managing the enterprise's future. However, an enterprise's competitive growth is generally defined based on pecuniary, trade and commerce performance, such as turnover, outputs, profitability, employee turnover rates, and asset return. In this paper, SMEs competitive growth is defined as the ability of the enterprise to access needed credit for its operational proficiency, innovativeness and expert business, and such consistently increase its market share, maintain productivity, increase staff retention, and consistently increase sales growth and profit. This implies that this paper sees an enterprise's competitive growth from the perspective of the four factors of access to finance for SMEs to attain competitive advantage in the Lesotho context. 


\section{Conceptual framework}

The Figure 1 below shows the conceptual framework of the study and indicated by the four selected factors of access to finance influence on competitive growth of SMEs.

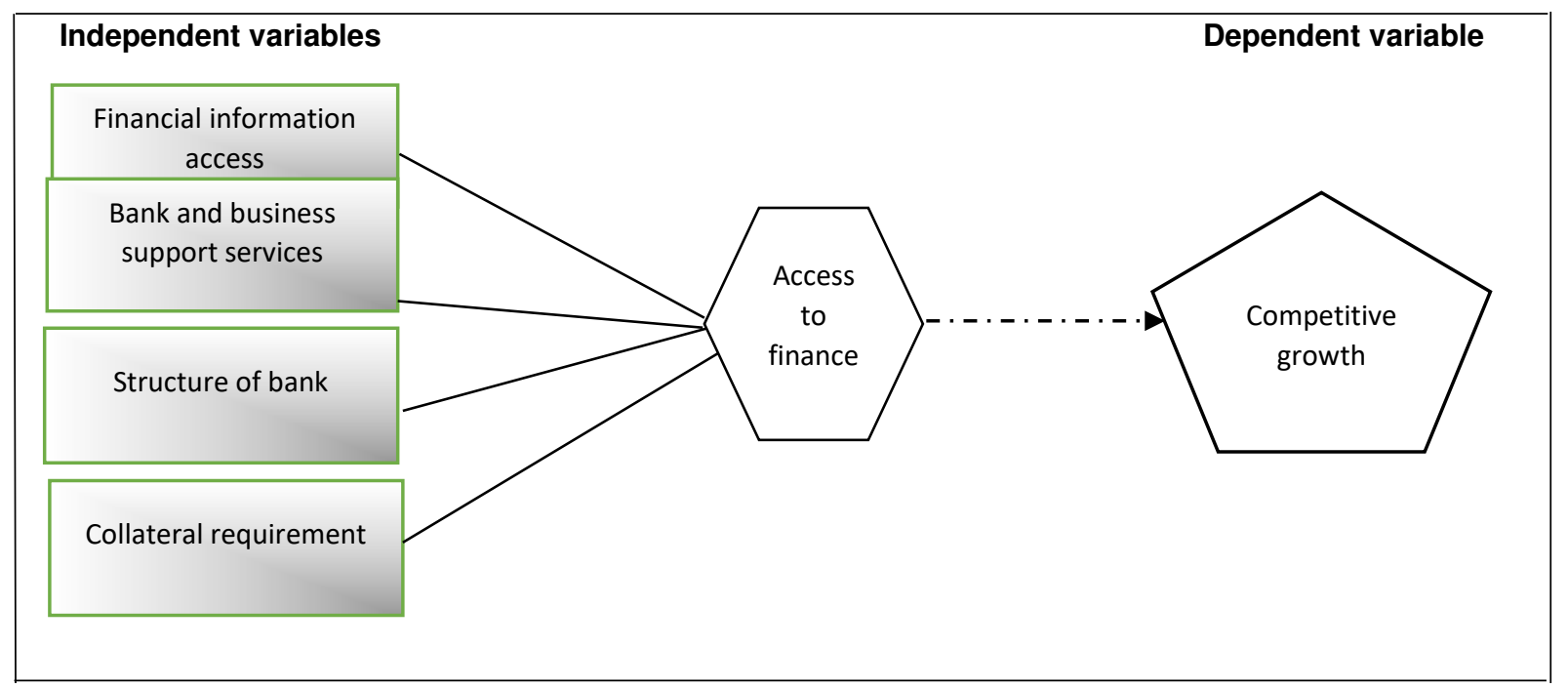

Figure 1: Selected factors of access to finance

\section{Methodology}

This study adopted the descriptive-correlation research design to analyze the influence of access to finance factors, namely financial information access, bank and business support services, the structure of bank and collateral requirements on the competitive growth of SMEs.

\section{Sample size and technique}

The survey sample size was 400 SMEs from Lesotho's four main districts (Butha-Buthe, Leribe, Mafeteng and Maseru). These four districts are chosen from the ten districts because Basotho SMEs are more represented in the selected districts than other districts (Berea, Mohales-Hoek, Mokhonlong, Qachas-nek, Quthing, Thaba-tseka) that make up Lesotho. However, the study considered Basotho SMEs that employed 6 to 50 people and registered with the Ministry of Small Business Development Cooperative and Marketing (GoL, 2016). The stratified random sampling technique was used to select respondents in the four designated districts. The reliability level of $95 \%$ and sampling error of $+/-5$ percent indicated that the 400 sample size was adequate.

The response rate was $96 \%$, and this gave a total valid 384 respondents that were used in the study analysis. The high response rate was because the researcher and research assistants were familiar with the four districts, and eight weeks were spent collecting feedback without duress on respondents.

\section{Measures}

The scale proposed by Aleksandr et al. (2016) was considered as a measure for financial information access. The financial information access predictor considered inadequate financial information on; available credit funding, financial programmes, agencies provisions items. Bank and business support services and bank structure considered selected items from Zeebaree and Siron (2017) and Osano and 
Languitone (2016). The items considered for bank and business support services relate to inadequate policy initiatives, support programmes, financial schemes and funding programmes. Structure of bank considered item such as low competition, system regulation, legal status and ownership pattern. The collateral requirement scale adopted selected items from Mazanai and Fatoki (2012), Kihimbo et al. (2012) and Ingabire et al. (2016). The predictor items from various authors were selected because they represent access to finance in the context of the study. This suggests that the measure of the four factors of access to finance (financial information access, bank and business support services, structure of bank and collateral requirement) considered some scale of items that measure bank perception of the SMEs, experience and behaviour of banks to SME operators of the mentioned four items.

The research tool comprised of a 19-item (Amadasun, 2020). The predictor scale measured four facets: financial information access ( 3 items, e.g. "inadequate information available on credit opportunities and programmes to SMEs"); bank and business support services (3 items, "inadequate support programmes such as financial schemes and credit programmes are in my district designed to support my enterprise"); structure of bank ( 5 items, e.g. "low competition in the banking sector has greater constrains on SMEs access to credit"); collateral requirement (4 items, e.g. "collateral requirement is a major constrains to my enterprise's access to credit funding from the bank"); and competitive growth (4 items e.g. "it is very difficult for my enterprise to retain customer patronage, maintain sale growth and profit, and manage staff turnover"). The study adopted the seven-Likert scale response rate format, ranging from 1 = "strongly disagree" to $7=$ "strongly agree". The research tool indicated that the higher the scores, the higher the level of agreement by respondents. The Cronbach alphas ranged from 0.755 to 0.861 for all the variables.

\section{Data analysis}

Before the analysis, to ensure that the test indicated minimal measurement error, necessary validity tests such as the content validity and reliability tests were first used to ensure that quality was maintained. This was followed by the correlation and regression analysis, and results are presented in subsequent tables in the analysis section.

\section{Results}

This paper opines that understanding the concept "access to finance" is explained by the critical factors such as financial information access, bank and business support services, bank structure, and collateral requirement effect on SMEs competitive growth in Lesotho. First, the SME questionnaire for this analysis was further subjected to various tests such as validity tests and reliability tests, and other subsequent analyses indicated that tests were consistent with the descriptive and explorative statistics used in the study.

\section{Validity and reliability scale}

\section{Confirmatory measures}

Factor analysis was used to assess the interrelated facets that form each factor. The exploratory factor analysis (EFA) was used to identify the underlying constructs that explain the correlations among a set of 
factors. Since there were no preceding theories and factor loadings, the EFA was used to identify the factor pattern of the data. Bartlett's test of sphericity and the Kaiser-Meyer-Olkin (KMO) results showed that all observed factors of access to finance in the analysis loaded as anticipated. The total value of $\mathrm{KMO}$ was found to be 0.840 , and it is meritorious. Bartlett's test of sphericity was significant at 105 degrees of freedom. The determinant of the association matrix was 0.000 , which showed minimal multicollinearity in the factors (significant at $p<0.001$ ).

The total variances indicated that all four factors are appropriate to retain because they had a minimum of three significant loadings. The principal component analysis (PCA) of the factor loading of the four observed variables converged after five iterations of rotation hence, they were retained for further analysis. The EFA was used for the rotation, followed by the PCA using the Varimax with Kaiser Normalisation. The results indicated that all the items loading factors were above 0.3 on the agreed threshold sample of 350 and above (Hair et al., 2014).

\section{Reliability scales}

The Cronbach Alpha was used to assess the reliability of factors and the internal consistency of scale of the data. Five factors were obtained after running Cronbach's Alpha and EFA tests and the values obtained were above 0.7 ; hence, they are considered acceptable for exploratory analysis (Hair et al., 2014). See Table 1

\section{Table 1 Reliability outputs (factors after running Cronbach Alpha and EFA)}

\begin{tabular}{lccl}
\hline Factor & No. of items & Cronbach alphas & Decision \\
\hline 1. Financial information access & 3 & 0.859 & Adequate \\
2. Bank \& business support services & 3 & 0.861 & Adequate \\
3. Structure of bank & 5 & 0.774 & Adequate \\
4. Collateral requirement & 4 & 0.833 & Adequate \\
5. Competitive growth & 4 & 0.755 & Adequate \\
\hline
\end{tabular}

Source: Analysis 2021: Reliability coefficient: No. of factors $=5$

\section{Spearman's correlation analysis}

The Spearman's correlation shows the association analysis of all access to finance factors' (financial information access, bank and business support services, structure of bank and collateral requirement) and the degree to which each is associated with SMEs' competitive growth. Table 2 indicated that there is medium and higher effect of correlation between the four independent constructs to dependent factor (competitive growth), and such suggests direct relation to SMEs' competitive growth. 
Table 2: Spearman correlation of factors of access to finance

\begin{tabular}{|l|l|l|l|l|l|}
\hline Variables & $\begin{array}{l}\text { Financial } \\
\text { information } \\
\text { access }\end{array}$ & $\begin{array}{l}\text { Bank } \\
\text { business } \\
\text { support } \\
\text { services }\end{array}$ & $\begin{array}{l}\text { Structure of } \\
\text { bank }\end{array}$ & $\begin{array}{l}\text { Collateral } \\
\text { requirement }\end{array}$ & $\begin{array}{l}\text { Competitive } \\
\text { growth }\end{array}$ \\
\hline $\begin{array}{l}\text { Financial } \\
\text { information } \\
\text { access }\end{array}$ & 1 & 1 & & & \\
\hline $\begin{array}{l}\text { Bank \& business } \\
\text { support services }\end{array}$ & $0.44^{* *}$ & 1 & $0.39^{* *}$ & 1 & \\
\hline Structure of bank & $0.35^{* *}$ & $0.33^{* *}$ & $0.34^{* *}$ & 1 \\
\hline $\begin{array}{l}\text { Collateral } \\
\text { requirement }\end{array}$ & $0.37^{* *}$ & $0.33^{* *}$ & & \\
\hline $\begin{array}{l}\text { Competitive } \\
\text { growth }\end{array}$ & $0.54^{* *}$ & $0.36^{* *}$ & 0.31 & \\
\hline ** Correlation is significant at the 0.01 level (2-tailed) & \\
\hline
\end{tabular}

Source: Analysis 2021: No. of factors $=5$

Table 2 indicated that the following address the aim of the paper for further analysis

- The result showed a positive association between financial information access (FIA) and competitive growth (large effect), $r=0.54, p<0.05$.

- Analysis indicated a positive correlation between bank and business support services (Bbss) and competitive growth (medium effect), $r=0.36, p<0.05$.

- There is a positive association between the structure of the bank (SoB) and competitive growth (medium effect) $r=0.31, p<0.05$.

- The analysis indicated a positive correlation between collateral requirement and competitive growth (large effect), $r=0.74, p<0.05$.

In addition,

- The result showed a positive association between financial information access and bank and business support services $(r=0.44$, medium effect $p<0.05)$. A positive relationship between financial information access and collateral requirement $(r=0.37$, medium effect $p<0.05)$, and a positive association between bank and business support services and structure of bank $(r=0.33$, medium effect $p<0.05)$. There was a positive relationship between the structure of bank and collateral requirement $(r=0.389$, medium effect $p<0.05)$; a positive relationship between financial information access and collateral requirement $(r=0.37$, medium effect $p<0.05)$, and the association are positive and significantly related to SMEs' competitive growth (COMPGRO) (a large effect, $r=0.54$ ). 
The medium and high association between the predictors of access to finance to the dependent variable of competitive growth indicated a relatively positive and significant level of agreement of respondents that the predictors are related to the SMEs capacity and are associated with enterprises competitive growth. This probably suggests that the factors mentioned above as critical facets of access to finance that SMEs need to operate dynamically and attain competitive growth.

\section{Regression Analysis}

Regression techniques were adopted to establish the level of the relationship between factors and their validity fit. The specification of the regression model of access to finance was significant at the $95 \%$ level and with a $p$-value less than 0.05 . The regression model adopted subscribes to Muthee and Ngugi (2014) that, $y=\beta_{0}+\beta_{1 X_{1}}+\beta_{2} X_{2}+\beta_{3 X_{3}}+\beta_{4} X_{4}+\varepsilon$. Where: $y=$ dependent factor (competitive growth); $\beta_{0}=$ constant, $\beta_{1}-\beta_{4}=$ model coefficients; $X^{1}-X^{4}=$ predictors, namely, financial information access, bank and business support services, the structure of bank and collateral requirement; and $\varepsilon=$ error term.

The regression result of Table 3 below shows that $R=0.888$ and $R^{2}$ of 0.788 . The $R^{2}$ of this model fitness is 0.788 , which indicates that $79 \%$ of the variability of the dependent factor (competitive growth) is explained by the independent factors, and it fits well.

Adjusted $R^{2}$ gives an accurate estimation of the variance predicted by the covariates included in the model. The results indicate that the predictor factors predict competitive growth (adjusted $R^{2}=0.786$ ), and expressed as a percentage, the model explains $79 \%$ of the variance in competitive growth.

Table 3: Model summary (Coefficient of determination)

\begin{tabular}{|c|c|c|c|c|c|c|c|c|c|}
\hline Model & $\mathbf{R}$ & R-square & $\begin{array}{c}\text { Adjusted } \\
\text { square }\end{array}$ & $\begin{array}{c}\text { Std. error } \\
\text { of } \\
\text { estimate }\end{array}$ & $\begin{array}{c}\text { R. } \\
\text { square } \\
\text { change }\end{array}$ & $\begin{array}{c}\text { F. } \\
\text { change }\end{array}$ & df 1 & df 2 & $\begin{array}{c}\text { Sig. F. } \\
\text { change }\end{array}$ \\
\hline 1 & 0.888 & 0.788 & 0.786 & 0.34077 & 0.788 & 353.008 & 4 & 379 & 0.000 \\
\hline
\end{tabular}

Predictor: (constant), financial information access, bank and business support services, the structure of the bank and collateral requirement.

Dependent variable: competitive growth

Source: analysis 2021

Table 4 indicated an F-ratio value of 353.008 and explained that the group's analysis is not similar. This suggests significant differences between variations within the groups, and the $p<0.001$ shows strong evidence between group means, which justified that the model is suitable at $p<0.05$ significance level (the data fits the model). 
Table 4: Analysis of variance (ANOVA)

\begin{tabular}{|c|c|c|c|c|c|c|}
\hline \multicolumn{7}{|c|}{ ANOVA } \\
\hline \multicolumn{2}{|r|}{ Model } & \multirow{2}{*}{$\begin{array}{c}\begin{array}{c}\text { Sum of } \\
\text { square }\end{array} \\
163.968\end{array}$} & \multirow{2}{*}{$\begin{array}{l}\text { df } \\
4\end{array}$} & \multirow{2}{*}{$\begin{array}{c}\text { Mean square } \\
40.992\end{array}$} & \multirow{2}{*}{$\begin{array}{c}\mathbf{F} \\
353.008\end{array}$} & \multirow{2}{*}{$\begin{array}{c}\text { Sig. } \\
0.000\end{array}$} \\
\hline 1 & Regression & & & & & \\
\hline & Residual & 44.010 & 379 & 0.116 & & \\
\hline & Total & 207.979 & 383 & & & \\
\hline & $v$ & titive & & & & \\
\hline
\end{tabular}

Source: Analysis 2021

Thus, the null hypothesis $\left(\mathrm{H}_{0}\right)$ was rejected for the three factors (financial information access, bank and business support services and collateral requirement) of access to finance, and the alternative hypothesis was accepted. This is because the $p<0.05$ and was consistent with the analysis of Table 5 .

$\mathrm{H}_{1}$ : Factor 1 (financial information access) has a statistically significant influence on SMEs competitive growth.

$\mathrm{H}_{1}$ : Factor 2 (bank and business support services) significantly influences on SMEs competitive growth.

$\mathrm{H}_{1}$ : Factor 3 (collateral requirement) has a statistically significant influence on SMEs competitive growth.

In Table 5, the multiple regression analysis to establish the regression coefficient $(\beta)$ for the four predictors. From Table 5, the results indicated that financial information access, bank and business support services and collateral requirement have a unique statistically significant contributory influence (at $p<0.05)$ on SMEs' competitive growth. Accordingly, SME entrepreneurs are more likely to be constrained regarding finance due to the current collateral requirement factor (magnitude $77 \%$ ). This is followed by the inadequate financial information access needed by most SMEs from banks (the magnitude 27\%). Next was the inadequate financial schemes, funding programmes and other enabling resources which support SMEs attractiveness for bank credit (level 6\%). This suggests that for every collateral requirement, financial information access and bank and business support services non-constraint an SME has, their access to finance increases by $73.4 \%, 25.2 \%$ and $6 \%$ (if all other independent factors remain constant in each case), which will likely influence enterprises attaining competitive growth in Lesotho. Thus, Table 5 indicated that the structure of banks does influence SMEs access to bank loans but does not affect the enterprise's capacity to attain competitive growth in Lesotho. 
Table 5: Standardized coefficient

\begin{tabular}{|c|c|c|c|c|c|}
\hline \multicolumn{6}{|c|}{ Coefficients } \\
\hline \multirow[t]{2}{*}{ Model } & \multicolumn{2}{|c|}{$\begin{array}{l}\text { Unstandardised } \\
\text { coefficients }\end{array}$} & \multirow{2}{*}{$\begin{array}{l}\text { Standardised } \\
\text { coefficient } \\
\text { B }\end{array}$} & \multirow[t]{2}{*}{$T$} & \multirow[t]{2}{*}{ Sig. } \\
\hline & B & Std. error & & & \\
\hline 1 (constant) & 0.820 & 0.202 & 0.820 & 4.067 & 0.000 \\
\hline $\begin{array}{l}\text { Financial } \\
\text { information } \\
\text { access }\end{array}$ & 0.252 & 0.028 & 0.271 & 8.917 & 0.000 \\
\hline $\begin{array}{l}\text { Bank and } \\
\text { business support } \\
\text { services }\end{array}$ & 0.059 & 0.029 & 0.060 & 2.041 & 0.042 \\
\hline Structure of bank & -0.193 & 0.043 & -0.138 & -4.534 & 0.000 \\
\hline $\begin{array}{l}\text { Collateral } \\
\text { requirement }\end{array}$ & 0.734 & 0.028 & 0.771 & 26.009 & 0.000 \\
\hline
\end{tabular}

Source: Researcher's 2021 analysis

The equation below suggests the extent the four predictors contribute to the regression analysis, therefore, the substitution to the final equation becomes; $Y=0.820+0.271(F I A)+0.060(B b s s)$ -

\section{$0.138($ SoB $)+0.771($ COLLATA $)$.}

\section{Discussion}

This paper followed a descriptive and explorative approach, factor analysis, and assumed the Spearman correlation matrix and the regression analyses to address its objective. From the correlation analysis, the Spearman correlation results of access to finance factors (financial information access, bank and business support services, structure of bank and collateral requirement) showed a positive association amongst factors that had a medium and large effect on the competitive growth of SMEs in Lesotho. The analysis suggests that SMEs' access to finance is significantly linked to the association between the aforementioned factors to potentially gear enterprises for competitive growth in Lesotho.

Further robust analysis from various techniques of regression analysis such as coefficient of determination, analysis of variance and standardised regression coefficient summarily indicated that financial information access, bank and business support services and collateral requirement factors make a unique statistically significant contribution influence (at $p<0.05$ ) to SMEs competitive growth in Lesotho. In explicit terms, the positive and statistically significance of financial information access influence on competitive growth in the analysis suggests the following possibilities that adequate financial information available in the financial market de-exacerbates lenders perception of SMEs applicants being too highly risky and harmonises the perspective of high administrative lending costs by lenders. Thus, the positive significance between financial information access and competitive growth is consistent with the findings of Aleksandr et al. (2016). 
Furthermore, the analysis suggested a positive relationship between bank and business support services and competitive growth. Business support enabling resources such as training programmes, advisory, financial management training, machinery and equipment support was significant enough to ease SMEs access to finance and operate effectively to attain competitive growth. This significance between bank and business support services and competitive growth is congruent with the findings of Zeebaree and Siron (2017).

Moreover, results further indicated a significant relationship between collateral requirement and competitive growth, suggesting that most SMEs face a huge constraint in the financial market to access needed credit. The results suggest that to discourage demand for credit, banks insist on collateral almost equivalent to the credit needed, and such disenfranchised most SMEs applicants. This result is consistent with Mazanai and Fatoki (2012) findings and Ingabire et al. (2016). However, the bank structure was not a significant positive influence on SMEs' competitive growth, which is in contrast to Osano and Languitone's (2016) findings. This finding suggests that although there are three main banks in Lesotho, as indicated in the literature, bank structure does have a significant constraint on SME applicants in securing a loan from banks but does not influence the enterprises' capacity to attain competitive growth in Lesotho. In addition, the results indicated that a significant proportion of the SMEs applicants to banks failed to get credit loans, and such is explained in the findings of the relationship between predictors such as financial information access, bank and business support services and collateral requirement. These findings could serve as one of the answers to the wide differences of SMEs who fail to access bank loans on application, such that it affects their capacity to attain competitive growth in Lesotho.

\section{Limitation and outlook}

The factors of access to finance were limited to four facets, as indicated in the review, and the analysis was focused on SMEs, which constituted $18 \%$ of the total MSME sector in Lesotho.

\section{Conclusion}

In sum, the analysis suggests that critical factors of access to finance such as collateral requirement by banks, inadequate financial information access and inadequate bank and business support services constrain most SMEs in attaining competitive growth in Lesotho. Thus the analysis showed that the mentioned factors of access to finance significantly hinder SMEs access to adequate funds from banks and affect their capacity to attain competitive growth. Therefore, to reduce the constraints of access to finance that SMEs face, the study opines the need to promote the financial inclusion of credits to enterprises. This suggests the need for policy interventions geared to; harmonise collateral requirements by the bank, promote adequate financial information access to SMEs in all rural and urban districts of Lesotho, and improve bank and business support services to SMEs to enhance their capacity to stand a chance to access adequate loans from banks. This will gradually ease the problems of asymmetric information between SMEs loan applicants and the banks, ease access to loans, and influence enterprises' chances to attain competitive growth in Lesotho. 


\section{Declarations:}

\section{Abbreviation}

SMEs - Small and medium-sized enterprises

\section{Ethics approval and consent to participate}

This paper is drawn from the candidate's PhD thesis submitted to the University of South Africa on $26^{\text {th }}$ June 2020.

\section{Consent of publication}

Not applicable

\section{Availability of data and material}

The data generated and analyzed in the current study are included in this published article (and in the supplementary files)

\section{Competing interests}

There are no competing interests from the authors. The University of South Africa funded the survey as a bursary for the candidate's PhD study from 2017 to 2020. Hence, there are no financial and non-financial interests from the authors.

\section{Funding}

The University of South Africa funded the survey as a bursary for the candidate's PhD study. Therefore, this paper utilizes the data obtained during the survey from the four districts of Lesotho (namely, Butha-Buthe, Leribe, Mafeteng and Maseru) in 2019.

\section{Authors' contribution}

The first author Donald O.E. Amadasun did the preliminary writing, and the co-author Prof. Ashley T. Mutezo, supervised the study and reviewed the manuscript.

\section{Acknowledgements}

Mrs Retha Burger, the editor at the independent skills development facilitator Pretoria, South Africa.

\section{Waiver}

We kindly solicit a waiver of publication costs, as the corresponding author is from a developing country, Lesotho. 


\section{References}

Aleksandr, K., Jaroslav, B., Ludmila, K. \& Pavla, P. 2016. The Entrepreneurial Perception of SME Business Environment Quality in the Czech Republic. Journal of Competitiveness 8(1): 66-78.

Amadasun, E.O.D. 2013. An Assessment of Small Enterprises Access to Finance and Information in Lesotho. Master thesis; National University of Lesotho (Nul). Roma.

Amadasun, E.O.D. 2020. The Influence of Market-driven Strategies and Access to Finance on Competitive Growth of Small and Medium-Sized Enterprises in Selected Districts of Lesotho. Doctoral thesis; University of South Africa (Unisa). Pretoria.

Bhalla, A. \& Kaur, M. 2012. SMEs' Access to Finance: An analysis of Attitude and Decision-Making Criteria of Commercial Banks. Asia-Pacific Journal of Management Research and Innovation. 8(1): 69-76.

El- Said, H., Al-Said, M. \& Zaki, C. 2015. Trade and Access to Finance of SMEs: Is there a Nexus? Journal of Applied Economics, 47(39): 4184-4199. doi: 10.1080/00036846.2015.1026583.

EU/European Union. 2012. Improving Access to Credit under Credit Guarantees. The Remark by the Head of the European Union to Lesotho, Maseru.

Fetisovova, E. et al. 2012. Current Problems of Finances of SMEs. Bratislava: Ekonom. ISBN 978-80225-3366-9.

Gathii, K.J., and Ngura, M.W. 2015. Socio-Economic Determinants of Performance of Small and Medium Enterprises (SMEs) in Gilgil Town of Nakuru County, Kenya. Journal of Humanities and Social Sciences, 20(8): 109-115.

Ghosh, S. 2016. Small Business, Lending Relationships and Crisis: Evidence from Indian Microdata. Indian Institute of Management Calcutta, 43(1):1-15.

GoL/Government of Lesotho. 2012. Kingdom of Lesotho: Ministry of Trade, Industry, Cooperatives and Marketing; Trade Capacity Assessment and Action plan. Maseru.

GoL/Government of Lesotho. 2016. The FinScope MSME Survey Lesotho 2015. Maseru.

Hair, J.F., Hultt, G.T.M., Ringle, C. \& Sarstedt, M. 2014. A Primer on Partial Least Squares Structural Equation Modeling (PLSSEM). SAGE Publications, Inc.

Ingabire, J.F., Shukla, J. \& Memba, F. 2016. Effects of Rural Small and Microenterprise Promotion Project- Phase II on Growth of SMEs in Rwanda: A Case of Nyange Sector- Musanze District. The International Journal of Business and Management, 4(2): 429-441.

Kihimbo, B., Ayako, B.A. \& Omoka, K.W. 2012. Collateral Requirement for Financing of Small and Medium Enterprises (SMEs) in Kakamega Municipality in Kenya. International Journal of Current Research, 4(6): 21-26.

Kremp, E. \& Sevestre, P. 2013. Did the Crisis induce Credit Rationing for French SMEs? Journal of Banking and Finance, 37: 37573772.

Makhetha, L. \& Sebolelo, P. 2015. Problems and Prospects of SMEs Loan Management: Case of Lesotho. International Journal of Recent Research in Interdisciplinary Sciences, 2(1): 24-31.

Matharu, S.K., Changle, R. \&Chowdhury, A. 2016. A Study of Motivational Factors of Women Entrepreneurs. The IUP Journal of Entrepreneurship Development, 34(1): 33-46.

Mazanai, M. \& Fatoki, O. 2012. Access to Finance in the SME Sector: A South African Perspective. Asian Journal of Business Management, 4(1): 58-67.

Mokoatleng, M.A. 2015. Small and Medium Enterprises' Access to External Financial in Lesotho. MBA thesis, University of the Free State, Bloemfontein.

Moro, A. \& Fink, M. 2013. Loan Managers' Trust and Credit access for SMEs. Journal of Banking and Finance, 37: $927-936$.

Muthee, M., and Ngugi, K. 2014. Influence of Entrepreneurial Marketing on the Growth of SMEs in Kiambu Town-CBD, Kenya. Journal of Business Management, 1(11): 361-377.

Osano, H.M. \& Languitone, H. 2016. Factors Influencing Access to Finance by SMEs in Mozambique: Case of SMEs in Maputo Central Business District. Journal of Innovation and Entrepreneurship, 5(13): 1-16. Doi 10.1186/s13731-016-0041-0.

Singh, F. \& Kaur, M. 2014. Small and Medium Enterprises' Awareness Regarding Export Credit Delivery System. Management and Labour Studies, 39(1): 63-79.

Stiglitz, J.E. \& Weiss, A. 1981. Credit Rationing in Markets with Imperfect Information. The American Economic Review, 71: 393419. 
Subairu, H.T. 2016. Analysis of Relationship between SMEs Employment Growth and Firm Specific Characteristics. Arabian Journal of Business and Management Review (OMAN Chapter), 5 (8): 30 -39.

Zeebaree, M.R.Y. \& Siron, R.B. 2017. The Impact of Entrepreneurial Orientation on Competitive Advantage Moderated by Financing Support in SMEs. International Review of Management and Marketing, 70(1): 43-52 